\title{
Study on Drivers' Behaviour Relationships to Reduce Road Accidents in Puchong, Selangor Darul Ehsan
}

\author{
(Kajian Hubungan Kelakuan Pemandu Bagi Mengurangkan Kemalangan \\ Jalan Raya di Puchong, Selangor Darul Ehsan) \\ Amiruddin Ismail, Gan Soon Yi* \& Mohd Kamarul Ifzam Mohd Zain
}

\begin{abstract}
Road accidents are the most common phenomenon in our daily life which occurs in every part of the world. In Malaysia, these issues took away many precious lives despite causing problems to the living family. Based on the Global Status Report, World Health Organisation (WHO) on Road Safety, Malaysian road users are categorized as the worst in South East Asia with an average of 23.8 deaths per 100,000 populations. One of the main factors that contribute the issue is drivers' behaviour. Moreover, this study was conducted to investigate the relationship between drivers'attitude towards road accidents in urban areas. Puchong in Selangor was selected and identified to have numerous cases of road accidents. Descriptive data of road accidents in Puchong were analysed to gain the results in graphical and numerical form. The causes of road accident due to driving's behaviour were verified through the developed drivers' behaviour model. A related suggestion has been stated based on this study to reduce and prevent the road accident at the studied area.
\end{abstract}

Keywords: Drivers'behaviour; road accidents; drivers' behaviour model

ABSTRAK

Kemalangan jalan raya adalah fenomena biasa yang berlaku dalam kehidupan seharian di setiap pelosok dunia. Di Malaysia, kemalangan jalan raya telah mengorbankan banyak nyawa di samping menyusahkan keluarga yang masih hidup. Berdasarkan Laporan Status Global, Pertubuhan Kesihatan Sedunia (WHO) mengenai keselamatan jalan raya, pengguna di Malaysia dikategorikan sebagai pengguna yang paling teruk di Asia Tenggara dengan 23.8 purata kematian bagi setiap 100,000 penduduk. Antara punca kemalangan yang paling utama adalah tingkahlaku pemandu. Justeru, kajian ini dijalankan bagi mengenalpasti perhubungan di antara sikap pemandu dengan kemalangan jalan raya di kawasan bandar utama. Puchong di Selangor dipilih dan dikenalpasti mempunyai antara rekod statistik kemalangan yang paling tinggi. Data-data deskriptif kemalangan jalan raya di Puchong dianalisis bagi mendapatkan keputusan secara grafik dan numerikal. Punca kemalangan yang disebabkan kelakuan pemandu diuji kesahihannya menggunakan model kelakuan pemandu yang dibangunkan. Beberapa cadangan dikemukakan berdasarkan hasil kajian ini bagi mengurangkan dan mengatasi masalah kemalangan yang berlaku di kawasan kajian.

Kata kunci: Kelakuan pemandu; kemalangan jalan raya; model kelakuan pemandu

INTRODUCTION

The increase of population and well-structured economy in Malaysia has led to the growth of car ownerships which indirectly caused higher rate of road accidents. According to the International Transport Forum (2013), Malaysia has been listed as the third highest number of death in road accident in 2011 among other developing countries. Drivers' behaviour is one of the main human factors which can contribute to the road accident (Liana et al. 2012). Therefore, this study aimed to investigate the relationship between drivers' behaviour towards reducing the road accidents.

Road accidents are the worst cases in Malaysia. In 2010, total road accidents that causing from this aspect is 414,421 cases (MIROS 2012). On this study, Puchong in Selangor was selected based on the highest rate of road accidents and keep increasing every year (JKJR 2012). High population in Puchong areas has caused the traffic flows that contribute to these issues (Jabatan Perangkaan Malaysia 2012). The main highway which connects Puchong to other town is Lebuhraya Damansara-Puchong (LDP). The high traffic flow has increased the accident rate in Puchong (LITRAK 2013). Based on the police report from Ibu Pejabat Polis Di Raja Malaysia Bukit Aman, the number of accident in Puchong in 2013 is 349 cases. There were 347 damage and 2 deaths. Furthermore, this study can help to create awareness to the public and also reduce and minimize the impact of road accident to the selected areas. 


\section{METHODOLOGY}

This study begins with conducting literature review, collecting data from related authorities, distributing and collecting of questionnaires. The obtained data were analysed using SPSS software to identify the drivers' behaviour which led to higher rate of road accident. Then, the major aspects of drivers' behaviour that contribute to the issue were identified through data analysis.

In methodology, primary and secondary sources were used in this study. For primary sources, questionnaires were developed and distributed randomly and equally in each location. In secondary sources, the data from authorities were collected and analyses were carried out on these data. Besides that, interview was conducted with the related authorities to obtain the details of drivers' behaviours in the study area. The survey was conducted in seven locations within Puchong urban areas which are Bandar Puteri, Bandar Puchong Utama, Bandar Bukit Puchong, Pusat Bandar Puchong, Bandar Kinrara, Taman Wawasan and IOI Boulevard. The sample size of the survey is 140 respondents. The questionnaire consists of three parts of questions which are respondent's personal information, point of view and driving habits.

\section{RESULT AND DISCUSSION}

There are three main factors that contributed to road accidents which are human, vehicle and road condition (Mohamad et al. 2011). Among these factors, human factor has the highest percentage that contributes to the road accidents which is 80 to $90 \%$ (Suraji \& Tjahjono 2012). It shows that generally of road accidents is caused by human factor, which refer to the behaviour of driver. Vehicle factor has the second highest percentage which means 10 to $30 \%$ of road accident is caused by vehicle factor. This factor refers to the ability of the vehicle to carry out its function successfully (Mohamad et al. 2011). There is only 5 to $15 \%$ of road accidents is caused by road condition factor. Road condition factor refer to the weather and road surface (Alonso et al. 2013). From this statement, it can be generally concluded that the main factor that contribute to the road accidents is human factor (Karim 2010). Drivers' behaviour is the major aspect of causing road accident. Drivers' behaviour that contribute to road accidents such as using mobile phone while driving, drunk driving, speeding, driving in hurry, improper overtaking car and dangerous driving (Vaughn et al. 2012). In Malaysia, motorcycle type almost contributed to the scene of the accident (Jabatan Perangkaan Malaysia 2012). The main factor that causes accident among the motorcyclists is also human factor (Suraji \& Tjahjono 2012).

\section{BEHAVIOUR OF IMPROPER OVERTAKING MANOEUVRES}

Figure 1 shows the answers of respondents in the statement of improper overtaking manoeuvres. In this statement, 13 respondents are strongly agree, 49 respondents are agree,
55 respondents are disagree and 23 respondents are strongly disagree. From the survey, there are more than $50 \%$ of respondents have disagreed of the statement of improper overtaking manoeuvres. An improper overtaking manoeuvre is dangerous behaviour which will make the other car driver can't well-respond immediately.

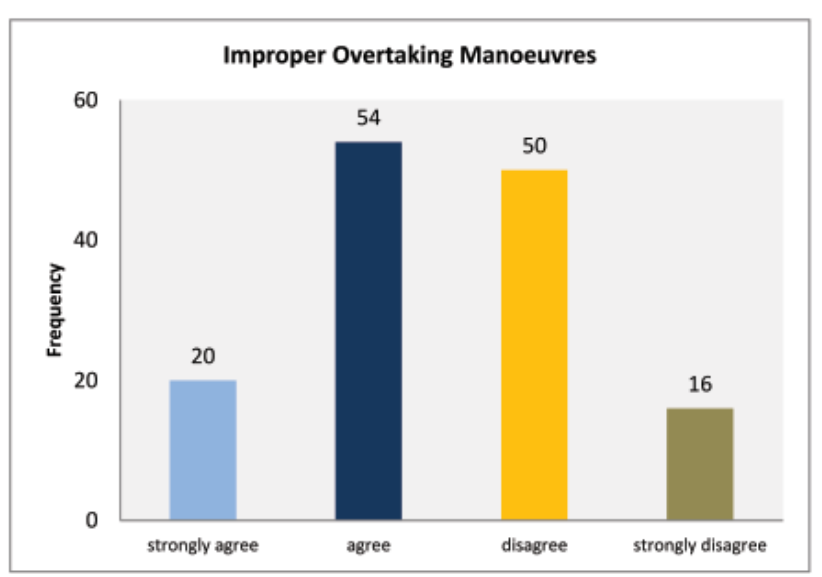

FIGURE 1. Improper overtaking manoeuvres

BEHAVIOUR OF SPEEDING

Figure 2 shows the result of survey data from the answers of respondents in the statement of speeding. There is only $35 \%$ of respondents have this behaviour. This indicates that majority of respondents have disagreed of the behaviour of driving over the speed limit.

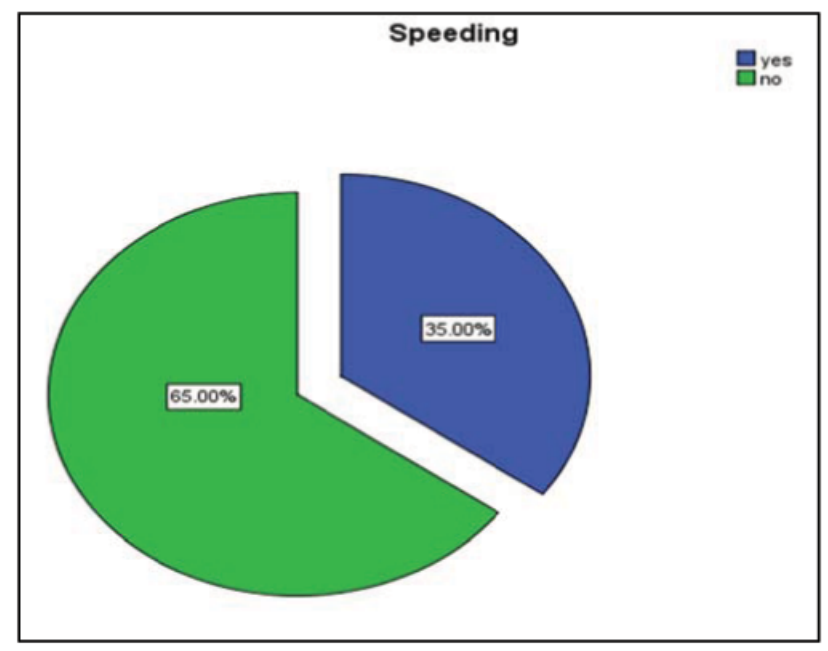

FIGURE 2. Total of respondents speeding percentage

Figure 3 shows the answer of respondents in the statement of driving over the speed limit. In this statement, 12 respondents are strongly agree, 49 respondents are agree, 71 respondents are disagree and 8 respondents are strongly disagree. This shows the majority of respondents have disagree of the 
statement of driving over the speed limit. Driver should be having good time management to avoid the behaviour of over speed limit driving.

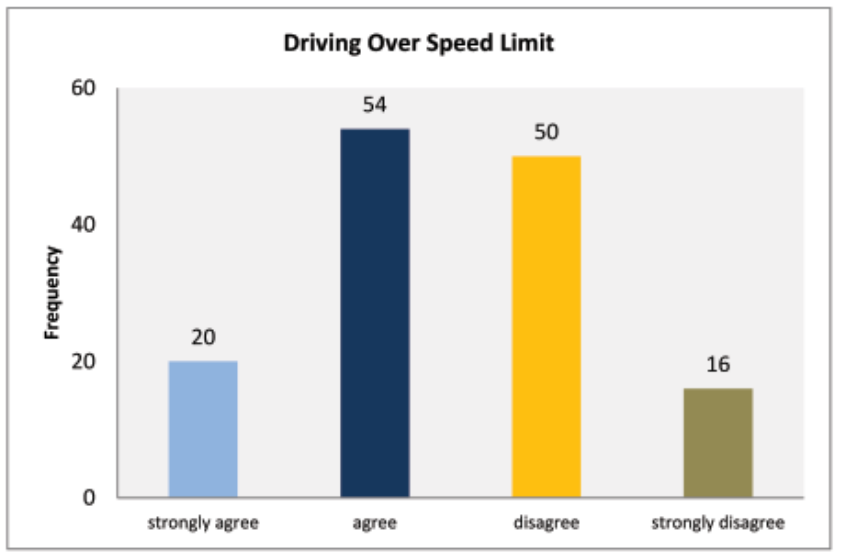

FIGURE 3. Driving over speed limit

BEHAVIOUR OF TAIL-GATING WHILE DRIVING

Figure 4 shows the result of survey data from the answers of respondents in the statement of tail-gating or following too closely while driving. In this statement, 16 respondents are strongly agree, 50 respondents are agree, 54 respondents are disagree and 20 respondents are strongly disagree. Based on the survey, there are more than $50 \%$ of respondents were disagreed of this aspect of drivers' behaviour. Tail-gating while driving is a negative posture which will increase the risk of accident. Tail-gating while driving will make the driver has no enough time to brake his car when emergency.

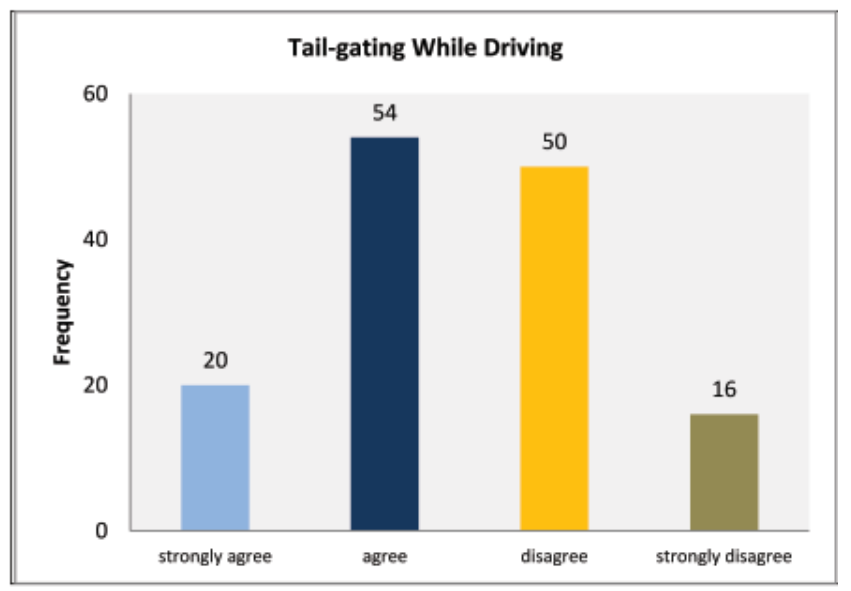

FIGURE 4. Tail-gating while driving

DRIVERS' BEHAVIOUR MODEL

In this study, a drivers' behaviour model has been developed to predict the relationship of driver's behaviours toward road accident. The model was developed by using the data from total of 140 respondents. By analyse the survey data, all the behaviours of driver were analysed to develop a linear regression between the accident occurrence history and the driving behaviours of the drivers by using SPSS package software. The main purpose of the model is to determine the probability of driver's involvement in the road accident. These three behaviours of drivers which are significant in the analysis have been chosen to develop the model. By using SPSS application, these three behaviours were selected to develop the model due to their significant test is lower than 0.05. These three factors are:

1. Improper overtaking manoeuvres;

2. Tail-gating while driving; and

3. Driving over speed limit.

The relationship of the 3 independent variables and the dependent variable is as follow:

$$
\begin{aligned}
\mathrm{Z}= & -0.805+0.110 \text { (overtaking) }+0.145 \text { (tail-gating) } \\
& +0.213 \text { (speed limit) }
\end{aligned}
$$

Where $\mathrm{Z}=$ linear combination

Probability of accident occurrence $=$

\section{1}

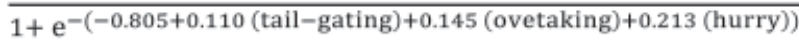

In the questionnaire, there are 4 answers provided in each statement which are strongly agree, agree, disagree and strongly disagree. The code of very agree is 4 , code of agree is 3 , code of disagree is 2 while code of very disagree is 1 .

For positive range, we put 1 into each independent variable. The probability of accident occurrence is 0.43 . As the probability of accident occurrence is lower than 0.5 , the accident will not occur.

$$
\begin{aligned}
\begin{array}{l}
\text { Probability of } \\
\text { accident } \\
\text { occurrence }
\end{array} & =\frac{1}{1+\mathrm{e}^{-(-0.805+0.110(1)+0.145(1)+0.213(1))}} \\
& =0.43
\end{aligned}
$$

For negative range, we put 4 into each independent variable. The probability of accident occurrence is 0.74 . As the probability of accident occurrence is higher than 0.5 , the accident will occur.

$$
\begin{aligned}
\begin{aligned}
\text { Probability of } \\
\text { accident } \\
\text { occurrence }
\end{aligned} & =\frac{1}{1+\mathrm{e}^{-(-0.805+0.110(4)+0.145(4)+0.213(4))}} \\
& =0.74
\end{aligned}
$$

Table 1 shows the difference between positive range and negative range of the probability of accident occurrence in the model. 
TABLE 1. Probability of accident occurrence

\begin{tabular}{lcc}
\hline Model & Positive range & Negative range \\
\hline $\begin{array}{l}\text { Probability of } \\
\text { accident occurrence }\end{array}$ & 0.43 & 0.74 \\
\hline
\end{tabular}

Nevertheless, validation of the model was done by conducting another survey again and data of 30 respondents were collected to verify the model. In the verifying stage, the data of 30 respondents were analysed by using SPSS. The results of significant variables were same with the previous analysis. The factors which are significant in this analysis are improper overtaking manoeuvres, tail-gating while driving and driving over the speed limit. Therefore, the model was verified and acceptable in this study. Moreover, another probability verification method was used to confirm the verification of the model. In this method, the accident predictions of 30 respondents are compared with the history of accident occurrence of the respondents. The verification shows that 18 respondents have been predicted correctly by using the model which is $63.33 \%$ accuracy.

Therefore, final modelling results which were obtained have showed that the factors that cause road accident are the following: improper overtaking manoeuvres, tail-gating while driving and over the speed limit. Based on the research of Alonso et al. (2013), overtaking is one of the factors that contributed to road accident. The most frequent error made by careless drivers in accidents was overtaking a vehicle that was turning right. This is because of young driver made a faulty overtaking decision and older driver made a faulty right turn (Alonso et al. 2013). In this developed model, this behaviour aspect is one of the factors which generally caused the road accident. This is majority caused by the wrong decision in young drivers. Furthermore, tail-gating is prevalent among drivers and potentially a factor in many rear-ends crushes. A possible explanation of tail-gating prevalence could be that drivers in general do not consider vehicle following distance to be an important road safety measure particularly that across the country no sign or bill board cautions drivers on following distance (Tlhabano et al. 2013). Tail-gating while driving is also one of the factors that caused road accident on this model. In the analysis of data, majority of young drivers have agreed of the statement of tail-gating while driving. Moreover, from the research of Alonso et al. (2013), the percentage of drivers (37.7\%) admitted that they are always, almost always or sometimes speed over the limit shows the urgent need to design and apply interventions to modify this behaviour. Therefore, speeding is one of the aspects that must be dealt with in order to reduce traffic crashes (Alonso et al. 2013). In this model, speeding over the speed limit has highest correlation towards the road accident occurrence. Finally, some suggestion such as organising road safety awareness campaign and enforcement of laws must be more proactive and consistence in order to reduce the road accident.

\section{CONCLUSION}

Generally, human factor is the major cause of road accident. The bad behaviour of driver will increase the risk of accident. Based on this study, the major behaviours of drivers which increase the road accident in Puchong are "improper overtaking manoeuvres", "driving over the speed limit" and "tail-gating while driving". Related program and campaign should be organized more frequent to increase the awareness of having a good drivers' behaviour.

\section{ACKNOWLEDGMENTS}

The authors would like to acknowledge the Sustainable Urban Transport Research Centre (SUTRA), Faculty of Engineering and Built Environment, Universiti Kebangsaan Malaysia (UKM) for providing research facilities. We would also like to express our profound gratitude and deep regards especially to the PDRM, MIROS and JKJR for providing fruitful advice and accidents data. Finally, thanks to the respondents for participating and completing the questionnaires.

\section{REFERENCES}

Alonso, F., Esteban, C., Calatayud, C. \& Sanmartin, J. 2013. Speed and road accidents: behaviours, motives, and assessment of the effectiveness of penalties for speeding. American Journal of Applied Psychology 1(3): 58-64.

Institut Penyelidikan Keselamatan Jalan Raya (MIROS). 2012. Laporan Penyelidikan 2012.

International Transport Forum. 2013. Annual Report 2013.

Jabatan Keselamatan Jalan Raya (JKJR). 2012. Laporan Tahunan MGRSP 2011-2012.

Jabatan Perangkaan Malaysia. 2012. Buletin Perangkaan Sosial.

Liana, N., Abdullah, L., Abdullah, I. \& Salleh, Z. 2012. Weights of road accident causes using analytics hierarchy process. ARPN Journal of Science and Technology 2(2): $39-44$.

Lingkaran Trans Kota Holdings Berhad (LITRAK). 2013. Annual report 2013.

Mohamad, G. M., Khairil, A. M. I. \& Tahir, M. P. 2011. Children, youth and road environment: road traffic accident. Asian Journal of Environment-Behaviour Studies 2(6): 13-20.

Karim, S. 2010. Kajian Kemalangan Jalanraya di km1.7 Hingga km2.1 Di Jalan Negeri Shah Alam - Batu Arang (B49) Daerah Petaling, Selangor Darul Ehsan. Johor: Universiti Teknologi Malaysia.

Suraji, A. \& Tjahjono, N. 2012. A confirmatory factor analysis of accidents caused by the motorcycle aspect in urban area. International Journal for Traffic and Transport Engineering 2(1): 60-69.

Tlhabano, K. N., Kote, M., Pheko, M. M., Monteiro, N. \& Balogun, S. K. 2013. Don't kiss my bumper: investigating tailgating driving behaviour in Botswana. IOSR Journal of Humanities and Social Science 12(1): 34-40. 
Vaughn, M. G., Salas-Wright, C. P. \& Piquero, A. R. 2012.

Buckle up: non-seat belt use and antisocial behaviour in the United States. Annals of Epidemiology 22(2): $825-831$

Amiruddin Ismail, Gan Soon Yi*

Mohd Kamarul Ifzam Mohd Zain

Sustainable Urban Transport Research Centre (SUTRA)

Department of Civil and Structural Engineering,

Faculty of Engineering and Built Environment

Universiti Kebangsaan Malaysia,

43600 UKM Bangi, Malaysia

*Corresponding author; email: csmsinny@yahoo.com

Received date: $3^{\text {rd }}$ July 2014

Accepted date: $7^{\text {th }}$ May 2015 